\title{
KARAKTERISASI MOLEKULER NUCLEOPOLYHEDROVIRUS (NPV) HYPOSIDRA TALACA WLK. DI PERKEBUNAN TEH GUNUNG MAS BOGOR
}

\author{
R. Yayi Munara Kusumah, Lestia Revi, \& Fitrianingrum Kurniawati \\ Departemen Proteksi Tanaman, Fakultas Pertanian, Institut Pertanian Bogor \\ Jl. Kamper Kampus IPB Dramaga, Bogor 16680 \\ E-mail:ymkusumah@gmail.com
}

\begin{abstract}
Characterize molecular the Nucleopolyhedrovirus (NPV) Hyposidra talaca Wlk. of tea plantation at Gunung Mas Bogor. Hyposidra talaca is one of the most important pest in tea plantation, and generally attacks of leaves and shoots. This pest cause yield loss up to 40-100\%. NPV can be pathogenic to the pest of $H$. talaca and can be developed as an alternative measure to control $\mathrm{H}$. talaca in tea plantations and based management appears to be more ecofriendly and effective. However, information regarding characterisation molecular of $H y t a \mathrm{NPV}$ is limited. The study conducted to characterize molecular the NPV of $H$. talaca by restriction nucleotide and amino acid, by using gens lef-8. Molecular identification used Polymerase Chain Reaction (PCR) consisted of DNA extraction, DNA amplication, and DNA electrophoresis. DNA amplication using gen lef-8 showed positif result with approximately $770 \mathrm{bp}$. Gen lef-8 can identified HytaNPV. DNA sequance showed that isolate HytaNPV Bogor had high homology of pathogonic NPV of genus Helicoverpa from Brazil, Australia, Spanyol and Netherland with homology nucleotide and amino acid reached $98 \%$ and $100 \%$. Based on philogeny tree of HytaNPV was one group with pathogenic NPV of genus Helicoverpa.
\end{abstract}

Key words: characterize NPV, gens lef-8, Hyposidra talaca, NPV

\begin{abstract}
ABSTRAK
Karakterisasi molekuler nucleopolyhedrovirus (NPV) Hyposidra talaca wlk. di perkebunan teh Gunung Mas Bogor. Larva Hyposidra talaca termasuk hama penting pada tanaman teh yang menyerang daun yang masih muda atau pucuk daun, hama ini dapat menyebabkan kerugian mencapai $40-100 \%$ jika tidak dilakukan pengendalian. Salah satu teknik pengendalian $H$. talaca yang sejalan dengan prinsip PHT yaitu memanfaatkan agen hayati seperti nucleopolyhedrovirus (NPV) yang memiliki inang spesifik, tidak membahayakan lingkungan, dapat mengatasi masalah keresistansian hama terhadap insektisida, dan selaras dengan komponen PHT lainnya. Namun, informasi mengenai karakterisasi molekuler HytaNPV masih sangat terbatas. Tujuan penelitian ini adalah mengetahui karakteristik molekuler melalui urutan nukleotida dan asam amino isolat NPV yang berasal dari $H$. talaca dengan menggunakan gen lef-8. Identifikasi molekuler dengan PCR terdiri beberapa tahap yaitu ekstraksi, amplifikasi dan elektroforesis DNA. Amplifikasi DNA HytaNPV menggunakan primer lef-8 berhasil mengisolasi gen lef- 8 HytaNPV dengan ukuran fragmen DNA sekitar 770 bp. Analisis urutan DNA berdasarkan gen lef-8 menunjukkan bahwa isolat HytaNPV Bogor tergolong ke dalam spesies virus yang memiliki hubungan kekerabatan yang dekat dengan isolat NPV yang menyerang genus Helicoverpa yang berasal dari Brazil, Australia, Spanyol dan Belanda dengan nilai homologi nukleotida dan asam amino sebesar $98 \%$ dan 100\%. Berdasarkan analisis filogeni, isolat HytaNPV masuk dalam grup yang sama dengan NPV yang menyerang genus Helicoverpa.
\end{abstract}

Kata kunci: DNA, gen lef-8, Hyposidra talaca, karakterisitik molekuler, NPV

\section{PENDAHULUAN}

Teh (Camelia sinensis L.) merupakan tanaman perkebunan penting di Indonesia dan menjadi salah satu penyumbang devisa negara yang cukup besar. BPS (2016) melaporkan bahwa produksi teh di Indonesia hanya mencapai sekitar $145.86 \mathrm{~kg}$ teh kering per hektar per tahun pada tahun 2013. Sedangkan, produksi teh tahun 2014 yaitu sekitar $142.72 \mathrm{~kg}$ per hektar per tahun.
Angka produksi tersebut masih tergolong rendah dibandingkan dengan produksi negara penghasil teh lainnya. Turunnya produksi sangat mungkin disebabkan oleh turunnya produktivitas tanaman. Menurut Widayat (1996), rendahnya produktivitas teh di Indonesia lebih banyak disebabkan oleh serangan organisme pengganggu tanaman (OPT) khususnya hama. Hama yang biasa menyerang tanaman teh adalah kepik daun teh (Helopeltis antonii), wereng pucuk teh (Empoasca 
sp.), ulat penggulung daun (Homona coffearia (L.) Nietn), ulat penggulung pucuk (Cydia leucostoma (L.) Meyr), dan ulat jengkal (Hyposidra talaca Wlk).

$H$. talaca merupakan hama penting pada tanaman teh (Ghosh et al., 2015). H. talaca umumnya menyerang daun yang masih muda atau pucuk daun. Serangan berat dapat menyebabkan daun berlubang dan pucuk tanaman gundul. Perkebunan teh milik PT. Perkebunan Nusantara VIII Gunung Mas, Bogor sering menemui permasalahan yang cukup serius akibat serangan hama H. talaca (Pradana, 2013). Kehilangan hasil akibat serangan $H$. talaca cukup tinggi, pada musim kemarau larva $H$. talaca dapat mengakibatkan kerugian mencapai 40-100\% apabila tidak dilakukan pengendalian (Muliani et al., 2011).

Pengendalian hama yang tepat dan bijaksana dapat mencegah kehilangan hasil dan menjaga kualitas serta keamanan produk. Undang-undang RI No. 12 tahun 1992 mencanangkan pelaksanaan pengendalian hama terpadu (PHT) yang melarang penggunaan sarana dan cara yang dapat mengganggu kesehatan manusia dan mencemari lingkungan (Widayat et al., 1996; Kunimi, 2007).

Nucleopolyhedrovirus (NPV) merupakan salah satu patogen serangga yang efektif sebagai agen pengendali serangga hama. NPV telah diuji efektif untuk mengendalikan ulat grayak dan ulat pemakan polong (Pramono, 2000; Arifin, 2006). NPV juga efektif untuk mengendalikan ulat jengkal (H. talaca) dan disebut juga $H y t a \mathrm{NPV}$ dengan persentase penurunan populasi hama 50-100\% dalam waktu 7-11 hari (Pradana, 2013). HytaNPV telah dilaporkan patogenik terhadap hama di laboratorium (Mukhopadhyay et al., 2011). NPV memiliki inang spesifik, tidak membahayakan lingkungan, dan sesuai dengan komponen PHT lainnya (Starnes et al., 1993).

NPV merupakan virus dari famili Baculoviridae yang mampu menginfeksi lebih dari 400 spesies serangga. Baculoviridae merupakan famili virus yang mampu menginfeksi serangga khususnya ordo Lepidoptera (Blissard et al., 2000). Informasi mengenai sekuens nukeleotida HytaNPV asal Indonesia saat ini belum ada di situs GenBank. Penelitian ini bertujuan untuk mengetahui karakteristik molekuler melalui urutan nukleotida isolat NPV yang berasal dari $H$. talaca di Perkebunan teh Gunung Mas Bogor dengan gen lef-8.

\section{METODE PENELITIAN}

Tempat dan Waktu. Sampel isolat NPV diperoleh dari perkebunan teh Gunung Mas Jawa Barat. Perlakuan dan pengolahan data dilakukan di Laboratorium Patologi
Serangga. Karakterisasi molekuler dilakukan di Laboratorium Virologi Tumbuhan, Departemen Proteksi Tanaman, Fakultas Pertanian, Institut Pertanian Bogor. Penelitian dilaksanakan dari bulan Februari sampai Mei 2016.

Isolasi NPV. Sampel cadaver ulat $H$. talaca yang menunjukkan gejala terserang NPV diambil dari perkebunan teh Gunung Mas. Cadaver digerus dengan mortar dalam larutan sodium deodecyl sulphate (SDS) $0,1 \%$, filtrat dituangkan ke dalam tabung mikro $2 \mathrm{ml}$, kemudian disentrifugasi dengan microsentrifuge Sorval Biofuge (Fresco) dengan kecepatan 2000 rpm selama 1 menit pada suhu $4{ }^{\circ} \mathrm{C}$. Pelet yang terbentuk dibuang, supernatan diambil dan disentrifugasi kembali dengan kecepatan $5000 \mathrm{rpm}$ selama 20 menit. Pelet yang terbentuk ditambahkan beberapa tetes aquabides (Cheng, 1998).

Pemurnian NPV terhadap $\boldsymbol{H}$. talaca. Pemurnian virus dilakukan dengan metode gradien sukrosa yang dibuat secara kontinyu pada tabung mikro $2 \mathrm{ml}$ (Grzywacz et al., 2011). Suspensi polihedra pada proses sebelumnya di sentrifugasi dalam gradien sukrosa dengan kecepatan 13.000 rpm selama 99 menit. Pita putih yang terbentuk diambil dengan menggunakan pipet pasteur kemudian ditambahkan beberapa tetes aquabides. Suspensi tersebut disentrifugasi kembali pada 7000 rpm selama 20 menit. Endapan yang terbentuk diambil dan diresuspensi dengan aquabides. Polihedra hasil purifikasi diamati di bawah mikroskop cahaya.

Pemurnian Virion dan Ekstraksi DNA. Hasil purifikasi sebelumnya diresuspensikan dengan larutan sodium karbonat $\left(\mathrm{Na}_{2} \mathrm{CO}_{3}, \mathrm{pH} 11\right)$, dan dikocok pelan pada suhu $37{ }^{\circ} \mathrm{C}$ selama 30 menit, kemudian disentrifugasi kembali menggunakan tabung mikro $2 \mathrm{ml}$ pada $13.000 \mathrm{rpm}$ selama $1 \mathrm{jam}$. Suspensi virion dimurnikan dengan metode yang sama pada pemurnian polihedra (Cheng, 1998), selanjutnya dilakukan ekstraksi DNA dengan menggunakan Viral nucleic acid extraction kit II (Geneaid).

Proses ekstraksi DNA genom virus meliputi beberapa tahapan yaitu pertama tahap lisis yaitu Sebanyak $200 \mu \mathrm{l}$ virion murni dimasukkan ke dalam tabung mikro kemudian $400 \mu 1 \mathrm{VB}$ lysis buffer ditambahkan. Suspensi tersebut dikocok menggunakan vortex kemudian diinkubasi pada suhu ruangan selama 10 menit. Selanjutnya tahap pengikatan asam nukleat, pada suspensi ditambahkan $450 \mu \mathrm{l} A D$ buffer, kemudian dipindahkan ke tabung mikro yang di dalamnya terdapat tabung kolom $V B$, kemudian disentrifugasi pada 13.000 
rpm selama 1 menit. Tahap pencucian: sebanyak $400 \mu \mathrm{l}$ W1 Buffer ditambahkan pada tabung kolom $V B$, kemudian disentrifugasi pada kecepatan $13.000 \mathrm{rpm}$ selama 1 menit. Pada tabung kolom $V B$ ditambahkan $600 \mu 1$ wash buffer, kemudian disentrifugasi kembali pada $13.000 \mathrm{rpm}$ selama 1 menit. Cairan yang tertampung pada dasar tabung mikro dibuang, kemudian disentrifugasi kembali pada $13.000 \mathrm{rpm}$ selama 3 menit hingga dasar tabung kolom $V B$ kering. Tahap terakhir yaitu elusi asam nukleat, tabung kolom $V B$ dipindahkan ke dalam tabung mikro yang baru, kemudian ditambahkan $50 \mu 1$ RNAase free water, dan didiamkan selama 3 menit. Setelah itu disentrifugasi pada kecepatan 13.000 rpm selama 1 menit. Cairan akhir yang tertampung di dasar tabung mikro merupakan DNA hasil ekstraksi. DNA kemudian di nano drop untuk melihat konsentrasi DNA hasil ekstraksi.

Amplifikasi DNA NPV Menggunakan PCR. Amplifikasi DNA menggunakan primer Gen lef-8 dengan urutan oligonukleotida primer forward 5'ATGAATTGCAAACTCTCCGCCCAG-3' dan reverse 3'-TCGACTGCAGACC-GCCGAAGA-5' (Kaur et al., 2014). Untuk amplifikasi isolat HytaNPV, sebanyak $2 \mu$ l DNA hasil ekstraksi dicampur dengan reagen yang terdiri atas $12,5 \mu \mathrm{l}$ Taq DNA polymerase,

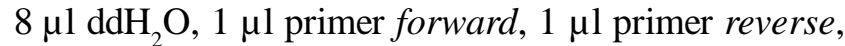
$0,5 \mu 1 \mathrm{MgCl}$ hingga volume akhir yang digunakan dalam amplifikasi sebanyak $25 \mu$ untuk satu reaksi. Amplifikasi dilakukan pada mesin PCR (gene amp system 9700). Satu siklus amplifikasi meliputi tiga tahapan utama yaitu: pradenaturasi $94{ }^{\circ} \mathrm{C}$ selama 5 menit, denaturasi $94{ }^{\circ} \mathrm{C}$ selama 1 menit, penempelan $61{ }^{\circ} \mathrm{C}$ selama 1 menit, ekstensi $72^{\circ} \mathrm{C}$ selama 1 menit, dan pasca ekstensi $72^{\circ} \mathrm{C}$ selama 7 menit, dengan suhu akhir penyimpanan $4{ }^{\circ} \mathrm{C}$. Siklus diulangi sebanyak 35 kali. Proses elektroforesis dilakukan dengan memasukan $5 \mu \mathrm{lDNA}$ hasil amplifikasi ke dalam sumur gel agarose $1 \%$ yang direndam dalam larutan Tris Borate EDTA (TBE) kemudian dialiri dengan arus listrik 50 volt selama 50 menit. Selanjutnya gel agarosa 1\% direndam dalam larutan Ethidium Bromida (EtBr) selama 30 menit. Visualisasi DNA dilakukan dengan cara meletakkan gel agarose pada UVtransiluminator kemudian difoto dengan menggunakan kamera.

Analisis Pengurutan DNA dan Pengurutan Asam Amino. DNA hasil amplifikasi dilakukan pengurutan fragmennya oleh $1^{\text {st }}$ BASE Singapura melalui PT. Genetica Science. Urutan nukleotida sampel dibandingkan dengan urutan nukleotida NPV lain yang telah dipublikasikan di situs National Centre for Biotechnology Information (NCBI) melalui program BLAST (Basic Local Alignment Search Tools). Data urutan nukleotida yang terpilih dianalisis menggunakan program penjajaran dan ClustalW serta program Bioedit ver 7.1.7 untuk mengetahui homologi nukleotida dan protein tiap sampel. Data asam amino dianalisis menggunakan situs www.expasy.com untuk menerjemahkan nukleotida menjadi asam amino. Data urutan asam amino dianalisis menggunakan program Bioedit ver 7.1.7.

Analisis Filogeni HytaNPV. Analisis filogeni dilakukan menggunakan pendekatan 'Neighbor-Joining' dengan Bootstrap 1000x dengan program MEGA 6 (Tamura et al., 2011).

\section{HASIL DAN PEMBAHASAN}

Pengambilan Sampel Hyposidra talaca yang Terserang NPV di Lapangan. Larva $H$. talaca yang menunjukkan gejala terinfeksi NPV di perkebunan teh diambil sebanyak-banyaknya. Larva yang terinfeksi sering ditemukan menggantung dengan kedua tungkai semu. Biasanya larva yang terinfeksi berwarna coklat

A

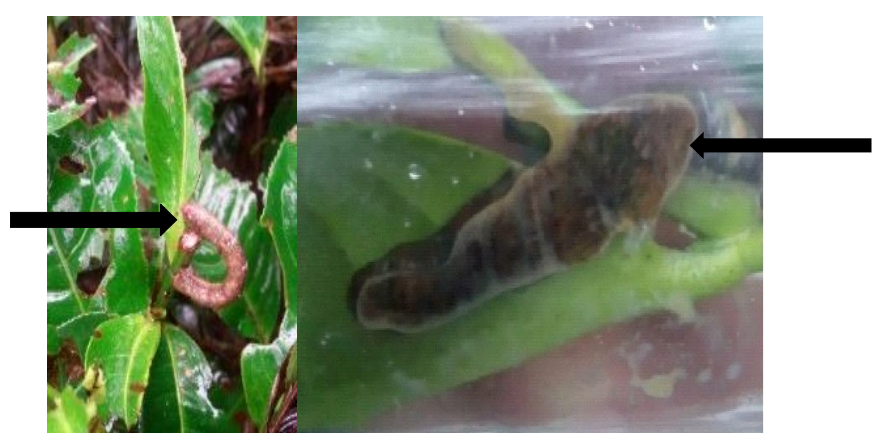

$\mathrm{B}$

Gambar 1 Larva $H$. talaca yang sehat (A), Larva $H$. talaca yang terserang NPV (B) 
kehitaman, jika bagian integumen pecah akan mengeluarkan lendir berwarna kecoklatan (Gambar 1).

Hasil Pemurian Virion NPV dan Nano Drop. Hasil sentrifugasi membentuk awan putih yang berkumpul di bagian tengah tabung yang merupakan kumpulan virion murni HytaNPV. Hasil nano drop virion murni menunjukkan bahwa konsentrasi DNA virion yaitu sebesar 50\%. Hasil tersebut dapat digunakan untuk bahan perbanyakan DNA dengan menggunakan metode PCR.

Pengamatan Polihedra HytaNPV. Polihedra HytaNPV diamati menggunakan mikroskop cahaya perbesaran 400x berbentuk seperti butiran-butiran kecil (Gambar 2). Ukuran dan bentuk polihedra NPV bervariasi tergantung spesiesnya (Cheng, 1998). Adapun bentuk polihedra yang pernah dilaporkan yaitu kuboid, dodecahedral, tetrahedral dan bentuk tidak beraturan. Pada umumnya polihedra HytaNPV berbentuk tetrahedral dengan diameter 0,476-0,274 $(\mu \mathrm{m}-\mathrm{SE})$ dan memiliki tipe multinukleotida (Lestari, 2008).

Karakterisasi Molekuler. Pengamatan karakter molekuler dengan amplifikasi DNA HytaNPV menggunakan primer forward dan reverse gen lef-8 menunjukkan hasil yang baik. Hal itu dilihat dari terbentuknya pita DNA sesuai dengan ukuran target yang diinginkan yaitu sekitar $770 \mathrm{pb}$ (pasang basa) (Gambar $3)$.

MetodePCR (Polymerase Chain Reaction) sangat sensitif untuk mengklasifikasikan Baculovirus. Gen lef8 merupakan salah satu gen transkripsi dalam genom Baculovirus yang merupakan gen ekspresi pada RNA polymerase yang cukup stabil mengkode subunit DNA dan menempelkan langsung pada RNA polymerase virus secara spesifik (Herniou et al., 2003). Gen late expression factor-8 (lef-8) merupakan gen yang banyak digunakan untuk menganalisis DNA NPV Lepidoptera (Acharya \& Gopinathan, 2002). Yu et al. (2013) telah mengarakterisasi gen late expression factor-10 (lef-10) dari Bombyx morii nucleopolyhedral virus.

Pengurutan Fragmen DNA HytaNPV. Fragmen nukleotida HytaNPV Bogor dikirim dalam bentuk kromatogram. Kromatogram HytaNPV menunjukkan hasil yang baik dengan tidak ada pengusutan yang terjadi pada kromatogram. Hasil fragmen berisi nukleotida forward dan reverse dicontig menggunakan software bioedit untuk mendapatkan sekuens lengkap dari HytaNPV.

Pengurutan DNA HytaNPV Bogor dilakukan untuk menentukan persentase kemiripan berdasarkan gen lef-8. Hasil BLAST diperoleh beberapa spesies NPV

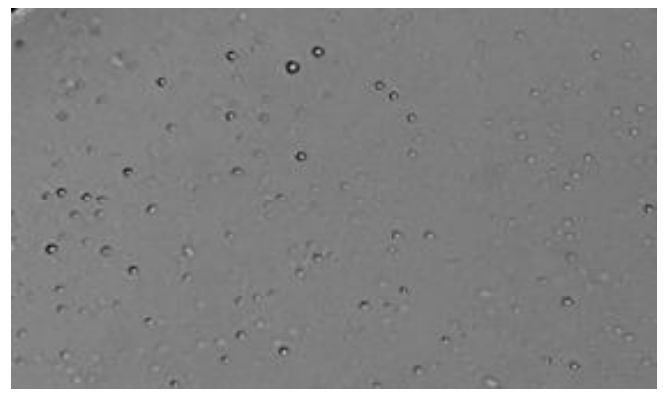

Gambar 2. Polihedra HytaNPV dibawah mikroskop cahaya (400x)

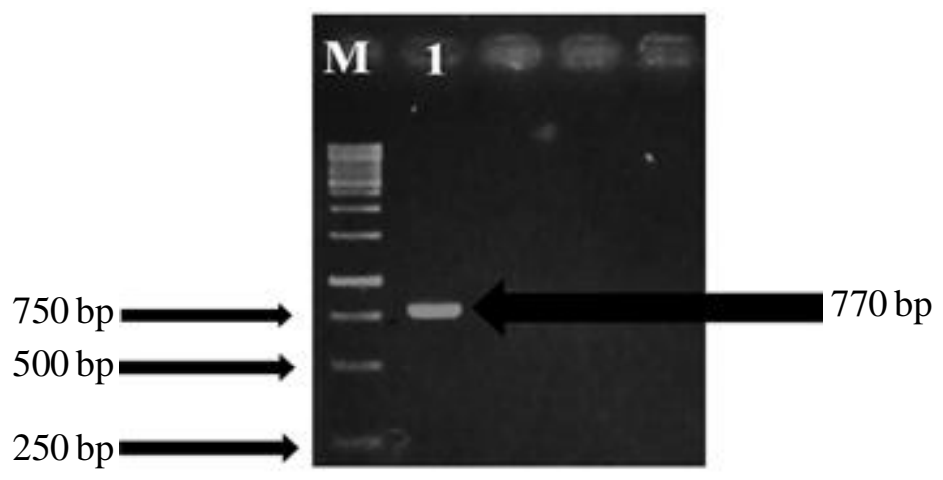

Gambar 3. Hasil visualisasi DNA HytaNPV Bogor menggunakan primer gen lef-8 Marker (M), HytaNPV (1) 
yang memiliki kemiripan yang cukup tinggi dengan isolat HytaNPV (Tabel 1). Parameter yang diamati pada hasil BLAST yaitu Query discovery yang berfungsi untuk mengetahui persen dari total panjang dari urutan nukleotida sampel yang cukup baik untuk disejajarkan dengan urutan nukleotida yang dimiliki oleh GenBank NCBI dan Max/total score berfungsi untuk mengetahui persen kesamaan antara urutan nukleotida sampel yang disejajarkan dengan urutan nukleotida bank data (Agustin, 2013). Dua spesies dikatakan identik jika memiliki persentase kemiripan $>73 \%$ (Li et al., 2009). Besarnya tingkat keragaman di dalam suatu spesies bergantung pada jumlah individu, penyebaran wilayah geografis, dan sistem genetiknya (Elrod \& Stansfield, 2007). Isolat HytaNPV Bogor memiliki nilai kemiripan tinggi dengan NPV yang menyerang genus Helicoverpa dengan persentase kemiripan mencapai 99\%. Nilai tersebut membuktikan bahwa sampel teridentifikasi sebagai NPV.

Hasil BLAST berdasarkan gen lef- 8 pada Tabel 1 menunjukkan bahwa isolat HytaNPV Bogor memiliki nilai max/total score yang tinggi dengan NPV yang menyerang genus Helicoverpa yaitu berkisar 1362 sampai 1380, untuk persentase kemiripan dan query discovery mencapai 99\%. Nilai max/total score pada NPV yang menyerang genus lain seperti dari genus Agrotis, Spodoptera, Bombyx, dan Mamesta memiliki nilai max/total score $\leq 500$, dengan persentase kemiripan dan query coverage sebesar $\leq 76 \%$ dan $98 \%$. Hal ini menunjukkan semakin tinggi nilai max/total score pada NPV yang menyerang suatu genus maka persentase kemiripannya semakin tinggi dengan sampel HytaNPV Bogor.

Homologi Nukleotida dan Asam Amino Hyta NPV. Karakterisasi molekuler dari susunan dan organisasi gen berfungsi menunjukkan hubungan evolusi diantara anggota Baculoviridae. Sekuen polihedrin baik nukleotida maupun asam amino digunakan untuk mengidentifikasi kekerabatan yang ditunjukkan oleh protein. Isolat HytaNPV dari Bogor memiliki nilai homologi nukleotida dan nilai homologi asam amino yang berbeda dengan 12 NPV yang menyerang genus lain yang terdapat di Genbank (Tabel 2 dan 3). Nilai homologi nukleotida dan asam amino tertinggi terdapat pada NPV yang menyerang genus Helicoverpa yaitu sebesar $98 \%$ dan $100 \%$.

Berdasarkan Tabel 2, homologi nukleotida isolat HytaNPV asal Bogor Jawa Barat menunjukkan kekerabatan tinggi, yaitu sebesar $98 \%$ dengan homologi nukleotida pada isolat HearNPV Australia (No. akses: JN584482.1), HearNPV Spanyol (No. akses: KJ701033.1), HeSNPV Australia (No. akses: KU738899.1), HezeNPV Brazil (No. akses: KM596835), HezeNPV Australia (No. akses:U67265.1), dan HezeNPV Belanda (No. akses: AF334030.1).

Selain keenam spesies Helicoverpa NPV, digunakan juga spesies pembanding dari NPV yang menyerang spesies lainnya dari ordo Lepidoptera. Tujuannya yaitu untuk melihat jarak kekerabatan antara

Tabel 1. Hasil BLAST gen lef-8 genom penuh (www.ncbi.nlm.nih.gov)

\begin{tabular}{lccccc}
\hline \multicolumn{1}{c}{ Asal } & Kode akses & $\begin{array}{c}\text { Panjang } \\
\text { DNA } \\
(\mathrm{pb})\end{array}$ & $\begin{array}{c}\text { Persentase } \\
\text { kemiripan } \\
(\%)\end{array}$ & $\begin{array}{c}\text { Query } \\
\text { coverage }\end{array}$ & $\begin{array}{c}\text { Max/total } \\
\text { score }\end{array}$ \\
\hline H. armigera NPV Australia & JN584482.1 & 130992 & 99 & 99 & $1362 / 1362$ \\
H. armigera NPV Spanyol & KJ701033.1 & 132265 & 99 & 99 & $1389 / 1389$ \\
H.SNPV Australia & KU738899.1 & 130435 & 99 & 99 & $1380 / 1380$ \\
H. zea sNPV Brazil & KM596835.1 & 129694 & 99 & 99 & $1380 / 1380$ \\
H. zea NPV Australia & U67265.1 & 6517 & 99 & 99 & $1380 / 1380$ \\
H. zea NPV Belanda & AF334030.1 & 130869 & 99 & 99 & $1380 / 1380$ \\
A. segetum NPV Poland & DQ123842.1 & 147544 & 75 & 97 & $500 / 500$ \\
S. exigua NPV Belanda & AF169823.1 & 135611 & 72 & 97 & $412 / 412$ \\
B. mori NPV Japan & AB009987.1 & 3682 & 72 & 97 & $407 / 407$ \\
M. configurata NPV Canada & U59461.2 & 155060 & 72 & 96 & $421 / 421$ \\
P. xylostella MNPV USA & DQ457003.1 & 134417 & 71 & 97 & $389 / 389$ \\
S. litura NPV Cina & AF325155 & 139342 & 70 & 98 & $345 / 345$ \\
\hline
\end{tabular}


Tabel 2. Persentase homologi nukleotida HytaNPV Bogor, Jawa Barat, gen lef-8 dengan sampel dari GenBank

\begin{tabular}{|c|c|c|c|c|c|c|c|c|c|c|c|c|c|}
\hline \multirow{2}{*}{$\begin{array}{l}\text { Asal } \\
\text { Isolat }\end{array}$} & \multicolumn{13}{|c|}{ Persentase homologi (\%) } \\
\hline & 1 & 2 & 3 & 4 & 5 & 6 & 7 & 8 & 9 & 10 & 11 & 12 & 13 \\
\hline 1 & ID & & & & & & & & & & & & \\
\hline 2 & 98.6 & ID & & & & & & & & & & & \\
\hline 3 & 98.6 & 100 & ID & & & & & & & & & & \\
\hline 4 & 98.8 & 99.7 & 99.7 & ID & & & & & & & & & \\
\hline 5 & 98.6 & 100 & 100 & 99.7 & ID & & & & & & & & \\
\hline 6 & 98.6 & 100 & 100 & 99.7 & 100 & ID & & & & & & & \\
\hline 7 & 98.8 & 99.7 & 99.7 & 100 & 99.7 & 99.7 & $\mathrm{ID}$ & & & & & & \\
\hline 8 & 73 & 73.5 & 73.5 & 73.5 & 73.5 & 73.5 & 73.5 & ID & & & & & \\
\hline 9 & 70.5 & 70.6 & 70.6 & 70.7 & 70.6 & 70.6 & 70.7 & 79.4 & ID & & & & \\
\hline 10 & 70.2 & 70.7 & 70.7 & 70.6 & 70.7 & 70.7 & 70.6 & 67.5 & 68 & ID & & & \\
\hline 11 & 71.5 & 71.4 & 71.4 & 71.5 & 71.4 & 71.4 & 71.5 & 75.8 & 75.5 & 66.5 & ID & & \\
\hline 12 & 0.355 & 35.2 & 35.2 & 35.2 & 35.2 & 35.2 & 35.2 & 35 & 35.6 & 35.5 & 34.2 & ID & \\
\hline 13 & 0.363 & 35.9 & 35.9 & 35.9 & 35.9 & 35.9 & 35.9 & 34.7 & 35.3 & 35.2 & 33.7 & 67.8 & ID \\
\hline
\end{tabular}

1. HytaNPV Bogor, 2. HearNPV Australia, 3. HearNPV Spanyol, 4.HeSNPV Australia, 5. HezeNPV Brazil, 6. HezeNPV Australia, 7. HezeNPV Belanda, 8. AgseNPV Poland, 9. SpexNPV Belandam, 10. BomoNPV Japan, 11. MacoNPV Canada, 12. PlxyMNPV USA, 13. SpliNPV Cina.

Tabel 3. Persentase homologi asam amino HytaNPV Bogor, Jawa Barat, gen lef-8 dengan sampel dari GenBank

\begin{tabular}{cccccccccccccc}
\hline \multirow{2}{*}{$\begin{array}{c}\text { Asal } \\
\text { Isolat }\end{array}$} & 1 & 2 & 3 & 4 & 5 & 6 & 7 & 8 & 9 & 10 & 11 & 12 & 13 \\
\hline 1 & ID & & & & & & & & & & & & \\
2 & 100 & ID & & & & & & & & & & & \\
3 & 100 & 100 & ID & & & & & & & & & & \\
4 & 100 & 100 & 100 & ID & & & & & & & & & \\
5 & 100 & 100 & 100 & 100 & ID & & & & & & & & \\
6 & 100 & 100 & 100 & 100 & 100 & ID & & & & & & & \\
7 & 100 & 100 & 100 & 100 & 100 & 100 & ID & & & & & & \\
8 & 78.6 & 78.6 & 78.6 & 78.6 & 78.6 & 78.6 & 78.6 & ID & & & & & \\
9 & 77.4 & 77.4 & 77.4 & 77.4 & 77.4 & 77.4 & 77.4 & 86.6 & ID & & & & \\
10 & 69.4 & 69.4 & 69.4 & 69.4 & 69.4 & 69.4 & 69.4 & 68.3 & 69.8 & ID & & & \\
11 & 76.2 & 76.2 & 76.2 & 76.2 & 76.2 & 76.2 & 76.2 & 83.7 & 80.3 & 63.3 & ID & & \\
12 & 69 & 69 & 69 & 69 & 69 & 69 & 69 & 67.9 & 69.4 & 98.8 & 63 & ID & \\
13 & 67.6 & 67.6 & 67.6 & 67.6 & 67.6 & 67.6 & 67.6 & 66.5 & 67.6 & 66.1 & 61.2 & 66.1 & ID \\
\hline
\end{tabular}

1. HytaNPV Bogor, 2. HearNPV Australia, 3. HearNPV Spanyol, 4.HeSNPV Australia, 5. HezeNPV Brazil, 6. HezeNPV Australia, 7. HezeNPV Belanda, 8. AgseNPV Poland, 9.SpexNPV Belanda, 10. BomoNPV Japan, 11. MacoNPV Canada, 12. PlxyMNPV USA, 13. SpliNPV Cina. 
isolat HytaNPV Bogor dengan spesies Lepidotera NPV lainnya. Homologi nukleotida HytaNPV Bogor dengan AgseNPV Poland (No. akses: DQ123842.1) sebesar 73\%, SpexNPV Belanda (No. akses: AF169823.1) sebesar 70\%, BomoNPV Japan (No. akses: AB009987.1) sebesar 70\%, MacoNPV Canada (No. akses: U59461.2) sebesar 71\%, PlxyMNPV USA (No. akses: DQ457003.1) sebesar 35\%, dan SpliNPV Cina (No. akses: AF325155) sebesar $36 \%$.

Isolat HytaNPV asal Bogor Jawa Barat pada tabel homologi asam amino menunjukkan kekerabatan tinggi dengan NPV yang menyerang genus Helicoverpa yaitu sebesar $100 \%$. Isolat HytaNPV jika dibandingkan dengan spesies lain nilai homologi asam amino dari ordo Lepidoptera tidak mencapai $80 \%$.

Berdasarkan hasil tabel homologi nukleotida dan tabel asam amino gen lef- 8 , HytaNPV diduga berasal dari spesies yang sama dengan NPV menyerang genus Helicoverpa karena memiliki nilai homologi nukleotida dan asam amino yang tinggi. Virus dikelompokkan ke dalam spesies yang sama apabila menunjukkan kesamaan

A

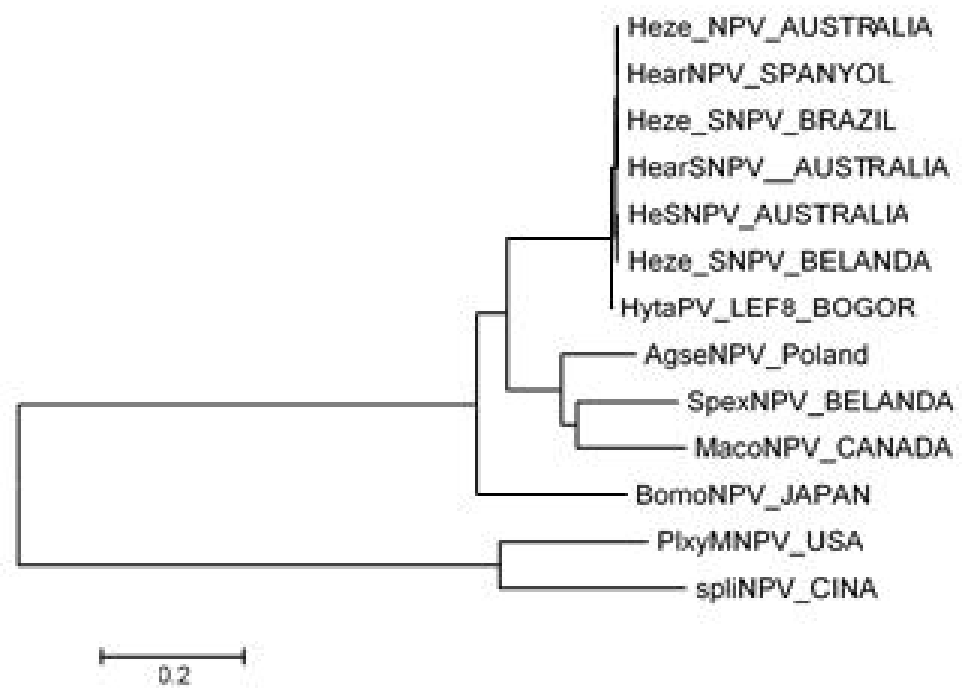

B

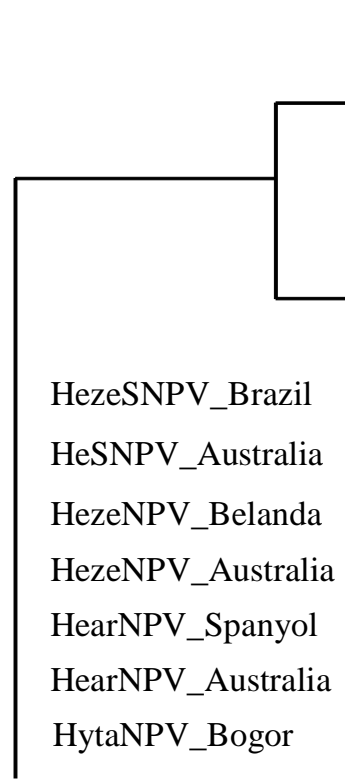

0.1

Gambar 4. Pohon filogeni urutan nukleotida NPV (A) dan filogeni urutan asam amino (B) diolah menggunakan software Mega 6 berdasarkan gen lef-8 menggunakan metode neighbour-joining dengan bootsrap 1000x. 
sekuen nukleotida (tingkat homologi) di atas 89\% (King et al., 2012).

Hasil tabel homologi urutan nukleotida dan urutan homologi asam amino dari setiap isolat menunjukkan perbedaan. Homologi urutan nukelotida mempunyai nilai kekerabatan terbesar sebesar $98 \%$ sedangkan pada homologi urutan asam amino mempunyai nilai mencapai $100 \%$. Adanya perbedaan urutan basa nukleotida pada HytaNPV dengan NPV yang menyerang genus Helicoverpa yang tidak menimbulkan perbedaan pada translasi dalam menghasilkan asam amino bisa terjadi karena adanya mutasi diam (silent mutation), yaitu perubahan suatu pasang basa dalam gen yang menimbulkan perubahan suatu kode genetik tetapi tidak mengakibatkan perubahan atau pergantian asam amino yang dikode (Stansfield et al., 2003).

Analisis Filogeni HytaNPV. Konstruksi pohon filogeni urutan nukleotida dan pohon filogeni urutan asam amino (Gambar 4) dengan menggunakan metode NeighborJoining (NJ) menunjukkan sedikit perbedaan pada percabangan antara HytaNPV dengan NPV lainnya. HytaNPV dari Bogor pada pohon filogeni NJ berada dalam kelompok yang sama dengan NPV yang menyerang genus Helicoverpa asal Australia, Belanda, Brazil, Spanyol, sedangkan NPV Lepidoptera dari genus lain berada pada kelompok yang terpisah.

\section{SIMPULAN}

Gen lef-8 berhasil mengidentifikasi HytaNPV, analisis urutan DNA berdasarkan gen $l e f-8$ menunjukkan bahwa isolat HytaNPV Bogor tergolong ke dalam spesies virus yang memiliki hubungan kekerabatan yang dekat dengan isolat NPV yang menyerang genus Helicoverpa yang berasal dari Brazil, Australia, Spanyol, dan Belanda dengan nilai homologi nukleotida dan asam amino sebesar $98 \%$ dan $100 \%$. Berdasarkan analisis filogeni, isolat HytaNPV masuk dalam grup yang sama dengan NPV yang menyerang genus Helicoverpa.

\section{SANWACANA}

Terimakasih kepada Perkebunan Gunung Mas PTPN 8, Laboratorium Virologi Tumbuhan dan Laboratorium Patologi Serangga, Departemen Proteksi Tanaman, Fakultas Pertanian Institut Pertanian Bogor atas kerjasama serta fasilitas penelitian yang telah diberikan selama penulis melaksanakan penelitian ini.

\section{DAFTAR PUSTAKA}

Acharya A \& Gopinathan KP. 2002. Characterization of late gene expression factors lef-9 and lef-8 from Bombyx mori nucleopolyhedrovirus. J. Gen Virol. 83: 2015-2023.

Agustin HSW. 2013. Analisis potensi bakteri kitinolitik asal limbah udang dan kepiting kandidat penghasil enzim kitinase serta anti jamur Saprolegnia sp. menggunakan marka molekuler gen 16S rRNA Tesis. Universitas Padjajaran. Bandung.

Arifin M. 2006. Kompatibilitas SINPV dengan HaNPV dalam pengendalian ulat grayak dan ulat pemakan polong kedelai. Penelitian Pertanian Tanaman Pangan 25(1): 65-70.

Blissard G, Black B, Crook N, Keddie BA, Possee R, Rohrmann G, Theilmann D, \& Volkman L. 2000. Family Baculoviridae. In: van Regenmortel MHV, Fauquet CM, Bishop DHL, Carstens EB, Estes MK, Lemon SM, McGeoch DJ, Maniloff J, Mayo MA, Pringle CR, \& Weckner RB (Eds.). Virus Taxonomy: Classification and Nomenclature of Viruses. pp. 195-202. Seventh Report of the International Committee for the Taxonomy of Viruses. Academic Press, San Diego.

[BPS] Badan Pusat Statistik 2016. Produksi Tanaman Perkebunan menurut Propinsi dan Jenis Tanaman, Indonesia (000 Ton), 2012-2015. BPS. Jakarta.

Cheng XW. 1998. Characterizatiom of two nuclearpolyhedrosis viruses from Thysanoplusia orichalcea (L.) (Lepidoptera: Noctuidae) from Indonesia. Dissertasion. Clemson University. Amerika Serikat.

Elrod SL \& Stansfield WD. 2007. Genetika. Damaringtyas (penerjemah). Erlangga. Jakarta.

Ghosh B, Mukhopadhyay A, Das A, \& Bahadur M. 2015. Restriction endonuclease fragment analysis of Hyposidra talaca nucleopolyhedrovirus genome. Int. J. Curr. Res. Aca. Rev. 3(8): 8187.

Grzywacz D, Rabindra RJ, Brown M, Jones KA, \& Parnell M. 2011. The Helicoverpa armigera NPV Manual Production. FAO http:// www.fao.org/docs/eims/upload/agrotech/2011/ hanpvmanual-pt2. pdf. Diakses pada 3 April 2016.

Herniou EA, Luque T, Chen X, Vlak JM, Winstanley D, Cory JS, \& O'Reilly DR. 2003. Use of whole 
genome sequence data to infer Baculovirus phylogeny. J. Virol. 75(17): 8117-8126.

King AMQ, Adams MJ. Carstens EB, \& Lefkowitz EJ. 2012. Virus Taxonomy Classification and Nomenclature of Viruses Nineth Report of the International Commite on Taxonomy of Viruses. Academic Press, San Diego.

Kaur B, Gupta VK, \& Jindal V. 2014. Molecular filogenetic analysis of Indian strains of Helicoverpa armigera nucleopolyhedrovirus (HearNPV). Indian J. Biotechnol. 13: 186-194.

Kunimi Y. 2007. Current status and prospects on microbial control in Japan. J. Invertebr. Pathol. 95: 181-186.

Lestari MP. 2008. Karakterisasi Morfologi dan Molekuler Nucleopolyhedrovirus (NPV) pada Hyposidra talaca Wlk (Lepidoptera: Geometridae). Skripsi. Institut Pertanian Bogor. Bogor.

Li Y, Yang BS, Wang H, Zia RX, Wang L, Zhang ZH, Qil L, \& Liu YQ. 2009. Mitochondrial DNA analysis reveals a low nucleotide diversity of Caligula japonica in China. Afr. J. Biotec. 8(12): 2707-2712.

Mukhopadhyay A, Khewa S, \& De D. 2011. Characteristics and virulence of nucleopolyhedrovirus isolated from Hyposidra talaca (Lepidoptera: Geometridae), a pest of tea in Darjeeling Terai, Indian. Int. J. Trop. Insect. Sci. 31(1-2): 13-19.

Muliani Y, Widayat W, \& Solihin A. 2011. Penggunaan jamur entomopatogen Paecilomyces fumusoroseus Bain. (PFR) terhadap mortalitas ulat jengkal (Hyposydra talaca Wlk.) hama pada tanaman teh (Camellia sinensis (L). O. Kuntze).
Dalam: Intan A, Putra RE, Turmuktini T, Muliani Y, Kantikowati E, Kinasih I, Meliansyah R, \& Bari IN (Eds.). Hidup Sejahtera Bersama Serangga. Prosiding Seminar Nasional Perhimpunan Entomologi Indonesia (PEI) Cabang Bandung. pp. 449-453. Bandung, 16-17 Februari 2011.

Pradana R. 2013. Pengelolaan Kebun dan Upaya Pengendalian Ulat Jengkal dengan Aplikasi Hyposidra talaca Nucleopolyhedrovirus pada Tanaman Teh di PT Perkebunan Nusantara VIII Gunung Mas Bogor Jawa Barat. Skripsi. Institut Pertanian Bogor. Bogor.

Pramono S. 2000. Efek penyimpanan terhadap virulensi nuclear polyhedrosis virus yang diaplikasikan pada tanaman kedelai terserang ulat grayak (Spodoptera litura Fabr.). J. HPT Tropika 1(1): 29-32.

Stansfield WD, Colome JS, \& Cano RJ. 2006. Schaum's Easy Outlines Biologi Molekuler dan Sel. Fahmi V (Penerjemah). Erlangga. Jakarta.

Starnes RL, Liu CL, \& Marrone PG. 1993. History, Use, and Future of Microbial Insecticides. American Entomologist, Amerika Serikat.

Tamura K, Peterson D, Peterson N, Stecher G, Nei M, \& Kumar S. 2011. MEGA5: Molecular Evolutionary. Cambridge University. Amerika Serikat.

Widayat W. 1996. Hama-hama pada Tanaman Teh dan Cara Pengendaliannya. Balai Penelitian Teh dan Kina, Gambung. Bandung.

Yu W, Du YC, Quan YP, Nie ZM, Chen J, Lv ZB, \& Zhang YZ. 2013. Characterization of late gene expression factor LEF-10 of Bombyx mori nucleopolyhedro virus. Virus Res. 175(1): 45-51. 